\title{
PENGARUH MODEL PROBLEM BASED LEARNING (PBL) TERHADAP KETERAMPILAN BERPIKIR KRITIS SISWA (KBKr) PADA SUB MATERI POKOK ALAT INDRA \\ (Penelitian Quasi Eksperimen pada Siswa Kelas XI SMA Negeri 9 Garut)
}

Elda Dewi Handayani, Tuti Kurniati dan Tri Wahyu Agustina Program Studi Pendidikan Biologi, Program Sarjana S1, Universitas Islam Negeri Sunan Gunung Djati Bandung

\begin{abstract}
The model of PBL learning is one of alternative way in which can be used to increase the critical thingking skills. The model of PBL learning include, student as participant to so solving problem and for create them as active participant in every solving problem process. In the concept of critical thingking the student aimed to test their ways of solving problem and can aware of mistakes. By using ouasi-experiment design research method and the research itself taking sample in purposive sampling. The population is all of class XI SMAN 9 garut student. The result of research shows that the student's critical thingking in which the senses material and also with the model of PBL shows the average around 88,51 than KBKr student using PBL model have their without. Score 87,15 the mann whitney test result, we have got $\mathrm{Z}_{\text {hitung }} \mathrm{Z}_{\text {tabel }}$ that is $1,0>1,66$ so that $\mathrm{H}_{\mathrm{a}}$ accepted and $\mathrm{H}_{\mathrm{o}}$ rejected, and the student response shows that the model of PBL is a lot of fun and can spread the positive impact, also in average, 3,60.
\end{abstract}

Key Words: Problem Based Learning , Critical Thingking Skills, The Senses.

\section{Pendahuluan}

Salah satu yang dihadapi dunia pendidikan kita adalah lemahnya proses pembelajaran. Dalam proses pembelajaran siswa kurang didorong untuk mengembangkan kemampuan berpikir. Pada pembelajaran IPA khususnya Biologi berkaitan dengan cara mencari tahu dan memahami alam secara sistematis, sehingga biologi bukan hanya penguasaan pengumpulan yang berupa fakta-fakta, konsep-konsep tetapi juga merupakan proses penemuan. Oleh karena itu butuh model pembelajaran yang digunakan harus sesuai, tidak cukup hanya ceramah dan hapalan saja. Peserta didik perlu diberi kebebasan dalam proses pembelajaran yaitu peserta didik harus lebih sering berperan aktif, berinteraksi dengan sesama peserta didik lain dan berpartisipasi di berbagai kegiatan dan mengatasi masalah. Dalam melaksanakan proses pembelajaran diperlukan langkah-langkah yang sistematik. Langkah sistematik inilah yang merupakan hal terpenting dalam menerapkan model pembelajaran yang tepat, sesuai, dan inovatif sehingga menunjang terciptanya kegiatan pembelajaran yang kondusif dan menarik bagi peserta didik.

Oleh karena itu dibutuhkan adanya suatu model yang dapat mengembangkan kualitas pendidikan, salah satunya dengan model Problem Based Learning (pembelajaran berbasis masalah) yaitu suatu tipe pengelolaan kelas yang diperlukan untuk mendukung pendekatan kontruktivisme dan mengakomodasi keterlibatan peserta didik dalam belajar. (Warsono, 2012:147)

\section{Problem Based Learning ( $\mathrm{Pbl})$}

Pembelajaran berdasarkan masalah atau PBL adalah suatu pendekatan yang efektif dalam pembelajaran yang digunakan 
untuk proses berfikir dalam situsi yang berorientasikan masalah termasuk didalamnya mengembangkan pengetahuan dasar dan komplek, serta diharapkan siswa menjadi seorang pembelajar mandiri. Salah satu metode yang banyak diadopsi untuk menunjang pendekatan pembelajaran learner centred dan yang memperdayakan pembelajar adalah model Problem Based Learning (PBL). PBL memiliki ciri-ciri seperti Tan (dalam Amir 2010:12) pembelajaran dimulai dengan pemberian 'masalah', biasanya 'masalah' memiliki konteks dengan dunia nyata, berkelompok aktif merumuskan masalah dan mengidentifikasi kesenjangan pengetahuan mereka,mempelajari dan menyari sendiri materi yang terkait dengan 'masalah', dan melaporkan solusi dari 'masalah'. Wee (2002) dalam Amir (2010:13) menyebutkan ciri proses PBL sangat menunjang pembangunan kecakapan mengatur diri sendiri (selt directed), kolaboratif, berfikir secara metakognitif, cakap menggali informasi.

\section{Tahapan Proses $(\mathrm{Pbl})$}

Ada tujuh tahapan dalam model pembelajaran berbasis masalah atau PBL seperti dinyatakan oleh amir (2010:24), ketujuh tahapan tersebut adalah: (1) Mengklarifikasi istilah dan konsep yang belum jelas, (2) Merumuskan masalah, (3) Menganalisis masalah, (4) Menata gagasan secara sistematis dan menganalisisnya dengan dalam, (5) Memformulasikan tujuan pembelajaran, (6) Mencari informasi tambahan, (7) Mengsintesa (menggabungkan) dan menguji informasi baru, dan membuat laporan.

\section{Keterampilan Berfikir Kritis}

$$
\text { Menurut Sutrisno, 2008; } 1
$$

keterampilan berfikir dapat didefinisikan sebagai proses kognitif yang dipecah-pecah kedalam langkah-langkah nyata yang kemudian digunakan sebagai pedoman berfikir. Satu contoh keterampilan berfikir adalah menarik kesimpulan (inferring), yang didefinisikan sebagai kemampuan untuk menghubungkan berbagai petunjuk (clue) dan fakta atau informasi dengan pengetahuan yang telah dimiliki untuk membuat suatu prediksi hasil akhir yang terumuskan. Terdapat tiga istilah yang berkaitan dengan keterampilan berpikir, yang sebenarnya cukup berbeda; yaitu berpikir tingkat tinggi (high level thingking), berpikir kompleks (complex thingking), dan berpikir kritis (critical thingking). Berfikir tingkat tinggi adalah operasi kognitif yang banyak dibutuhkan pada proses-proses berfikir yang terjadi dalam short-term memory. Berfikir kritis merupakan salah satu jenis berpikir yang konvergen, yaitu menuju kesatu titik.

\section{Pengembangan Tujuan}

Adapun tujuan dalam penelitian untuk mengetahui keterlaksanaan proses belajar siswa dengan menggunakan model PBL, mengetahui peningkatan $\mathrm{KBKr}$ siswa pada pembelajaran alat indra menggunakan model PBL, mengetahui peningkatan $\mathrm{KBKr}$ siswa pada pembelajaran alat indra tanpa model PBL, mengetahui pengaruh penggunaan model pembelajaran PBL terhadap $\mathrm{KBKr}$ siswa dalam pembelajaran alat indra, mengetahui respon siswa pada pembelajaran dengan menggunakan model PBL.

\section{Metode Penelitian}

Metode penelitian yang digunakan adalah metode Quasi-Experiment (Arikunto, 2006: 84). Penelitian ini menunjukkan untuk mengetahui ada atau tidak nya pengaruh model PBL terhadap KBKR pada materi alat indra. Dengan menggunakan model ini kelompok eksperimen maupun kelompok kontrol tidak dipilih secara random. Dengan model ini peneliti akan membandingkan kelas yang diberi perlakuan (kelas eksperimen) dan yang tidak diberi perlakuan (kelas kontrol) dengan model pembelajaran PBL.

Dari data populasi yang ada diambil dua kelompok sampel, yaitu kelompok eksperimen dan kelompok kontrol. Pada mulanya siswa diberikan tes awal (pretest) 
yang kemudian dilakukan suatu pembelajaran dengan menggunakan model PBL dan yang tanpa menggunakan model PBL, setelah itu diakukan tes akhir (posttest).

\section{Hasil Penelitian}

\section{a. KBKr Siswa yang Menggunakan Model PBL}

$\mathrm{KBKr}$ siswa diukur dengan menggunakan tes formatif yaitu tes awal dan tes akhir berbentuk essay. Berdasarkan hasil penelitian yang telah dilaksanakan diperoleh data tes awal dan tes akhir. Adapun data yang diperoleh dari nilai ratarata tes awal, tes akhir dan gain dapat dilihat pada tabel 1 sebagai berikut :

Tabel 1 Nilai Belajar Siswa Dengan Menggunakan Model PBL

\begin{tabular}{|c|l|c|c|c|}
\hline No & $\begin{array}{c}\text { Keterang } \\
\text { an }\end{array}$ & $\begin{array}{c}\text { Nilai } \\
\text { Terenda } \\
\mathbf{h}\end{array}$ & $\begin{array}{c}\text { Nilai } \\
\text { Terting } \\
\text { gi }\end{array}$ & $\begin{array}{c}\text { Nilai } \\
\text { Rata- } \\
\text { Rata }\end{array}$ \\
\hline 1 & Tes awal & 50.00 & 72.00 & 62,93 \\
\hline 2 & Tes akhir & 75.00 & 97.00 & 88,51 \\
\hline 3 & N-Gain & & & 0,69 \\
\hline
\end{tabular}

Berdasarkan tabel 1 tersebut dapat dibuat dalam diagram batang $\mathrm{KBKr}$ siswa menggunakan model PBL pada gambar 1 berikut ini.

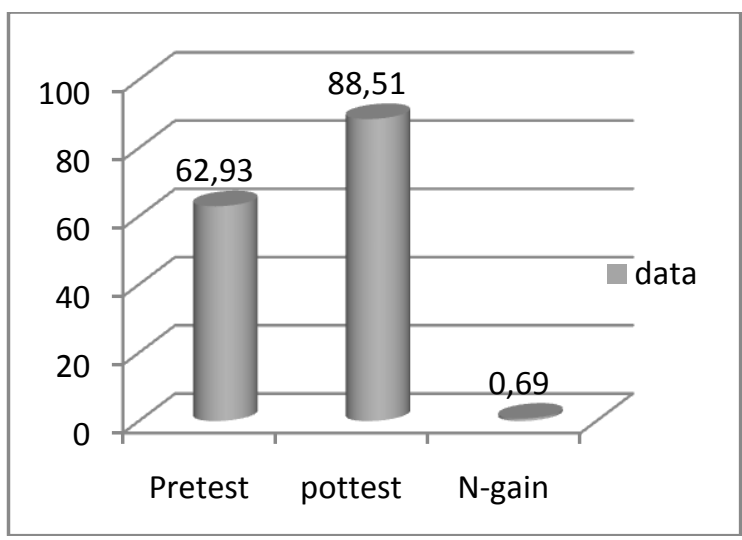

\section{Gambar 1 Diagram Keterampilan Berfikir Kritis Siswa dengan Model PBL}

Berdasarkan tabel dan diagram diatas, dapat dilihat nilai pretes kelas eksperimen dengan menggunakan model PBL memiliki nilai tertinggi 72.00 dan nilai terendah 50.00 dengan rata-rata nilai 62,93 (kriteria baik). Adapun nilai hasil dari tes akhir nilai tertinggi 97.00 dan nilai terendah 75.00 dengan rata-rata 88,51 (kriteria sangat baik). Sedangkan nilai $\mathrm{N}$-gain dari kelas eksperimen ini memiliki rata-rata 0.69 dengan criteria sedang.

Untuk mengetahui rata-rata nilai siswa yang didapatkan dari setiap indikator $\mathrm{KBKr}$ dan dari indikator pembelajaran, maka setiap indikator soal tersebut dianalisis.Hasil analisis berdasarkan indikator $\mathrm{KBKr}$ dapat dilihat pada tabel 2 berikut.

Tabel 2 Rata-Rata Indikator KBKr Kelas Eksperimen

\begin{tabular}{|c|c|c|c|c|c|}
\hline \multirow{3}{*}{ No } & \multirow{3}{*}{$\begin{array}{l}\text { Indikat } \\
\text { or } \\
\text { KBKr }\end{array}$} & \multicolumn{4}{|c|}{ Eksperimen } \\
\hline & & \multicolumn{2}{|c|}{ Pretest } & \multicolumn{2}{|c|}{ Postest } \\
\hline & & $\begin{array}{l}\text { Rata } \\
\text {-rata }\end{array}$ & $\begin{array}{l}\text { Kate } \\
\text { gori }\end{array}$ & $\begin{array}{l}\text { Rata } \\
\text {-rata }\end{array}$ & $\begin{array}{l}\text { Kateg } \\
\text { ori }\end{array}$ \\
\hline 1 & $\begin{array}{l}\text { Membe } \\
\text { rikan } \\
\text { Penjelas } \\
\text { an } \\
\text { Sederha } \\
\text { na }\end{array}$ & 54,40 & $\begin{array}{l}\text { Kura } \\
\text { ng }\end{array}$ & 68,25 & Baik \\
\hline 2 & $\begin{array}{l}\text { Memba } \\
\text { ngun } \\
\text { Ketera } \\
\text { mpilan } \\
\text { Dasar }\end{array}$ & 50,80 & $\begin{array}{l}\text { Kura } \\
\text { ng }\end{array}$ & 62,70 & Cukup \\
\hline 3 & $\begin{array}{l}\text { Menyi } \\
\text { mpulka } \\
\text { n }\end{array}$ & 41,67 & $\begin{array}{l}\text { Kura } \\
\text { ng }\end{array}$ & 65,45 & Cukup \\
\hline 4 & $\begin{array}{l}\text { Membe } \\
\text { rikan } \\
\text { Penjelas } \\
\text { an } \\
\text { Lanjut }\end{array}$ & 53,40 & $\begin{array}{l}\text { Kura } \\
\text { ng }\end{array}$ & 58,30 & Cukup \\
\hline \multicolumn{2}{|c|}{ Rata-rata } & 50,06 & $\begin{array}{l}\text { Kura } \\
\text { ng }\end{array}$ & 63,67 & Cukup \\
\hline
\end{tabular}

Berdasarkan tabel 2 di dapatkan hasil rata-rata indikator $\mathrm{KBKr}$ untuk kelas eksperimen diperoleh rata-rata pretest sebesar 50,06 dan posttest sebesar 63,67. Selaian mengetahui rata-rata nilai siswa yang didapatkan dari setiap indikator berpikir kritis, analisis nilai rata-rata siswa juga dapat dilihat dari indikator tiap-tiap soal pembelajaran. Hasil analisis 
berdasarkan indikator pembelajaran dapat dilihat pada tabel 3 berikut.

Tabel 3 Rata-Rata Indikator Pembelajaran Kelas Eksperimen

\begin{tabular}{|c|c|c|c|c|c|}
\hline \multirow[b]{3}{*}{ No } & \multirow{3}{*}{$\begin{array}{c}\text { Indikator } \\
\text { Pembelaja } \\
\text { ran }\end{array}$} & \multicolumn{4}{|c|}{ Eksperimen } \\
\hline & & \multicolumn{2}{|c|}{ Pretest } & \multicolumn{2}{|c|}{ Postest } \\
\hline & & $\begin{array}{l}\text { Rata } \\
\text {-rata }\end{array}$ & $\begin{array}{l}\text { Ka } \\
\text { teg } \\
\text { ori }\end{array}$ & $\begin{array}{c}\text { Rata } \\
- \\
\text { rata }\end{array}$ & $\begin{array}{c}\text { Kateg } \\
\text { ori }\end{array}$ \\
\hline 1 & $\begin{array}{l}\text { Mendeskri } \\
\text { psikan } \\
\text { pengertian } \\
\text { panca indra } \\
\text { manusia } \\
\text { menurut } \\
\text { Al-Qur'an } \\
\text { dan hadist }\end{array}$ & 51,59 & $\begin{array}{l}\text { Kur } \\
\text { ang }\end{array}$ & 62,70 & $\begin{array}{l}\text { Cuku } \\
\mathrm{p}\end{array}$ \\
\hline 2 & $\begin{array}{l}\text { Menjelaska } \\
\mathrm{n} \quad \text { contoh } \\
\text { penyakit } \\
\text { yang } \\
\text { terdapat } \\
\text { dalam } \\
\text { panca indra }\end{array}$ & 53,97 & $\begin{array}{l}\text { Kur } \\
\text { ang }\end{array}$ & 60,70 & $\begin{array}{l}\text { Cuku } \\
\text { p }\end{array}$ \\
\hline 3 & $\begin{array}{l}\text { Mengidenti } \\
\text { fikasi } \\
\text { fungsi } \\
\text { panca indra }\end{array}$ & 44,44 & $\begin{array}{l}\text { Kur } \\
\text { ang }\end{array}$ & 65,05 & $\begin{array}{l}\text { Cuku } \\
\mathrm{p}\end{array}$ \\
\hline 4 & $\begin{array}{l}\text { Menjelaska } \\
\text { n struktur } \\
\text { panca indra }\end{array}$ & 41,68 & $\begin{array}{l}\text { Kur } \\
\text { ang }\end{array}$ & 54,80 & $\begin{array}{l}\text { Cuku } \\
\text { p }\end{array}$ \\
\hline \multicolumn{2}{|c|}{ Rata-rata } & 47,92 & $\begin{array}{l}\mathrm{Ku} \\
\text { ran } \\
\mathrm{g}\end{array}$ & 60,81 & $\begin{array}{l}\text { Cuku } \\
\text { p }\end{array}$ \\
\hline
\end{tabular}

\section{b. KBKr Siswa Tanpa Menggunakan Model PBL}

Nilai rata-rata tes awal, rata-rata tes akhir, dan rata-rata gain hasil keterampilan berpikir kritis siswa tanpa menggunakan model PBL dapat dilihat pada tabel 4 sebagai berikut:

Tabel 4 Nilai Belajar Siswa Tanpa Model PBL

\begin{tabular}{|l|l|l|l|l|}
\hline No & $\begin{array}{l}\text { Keterang } \\
\text { an }\end{array}$ & $\begin{array}{l}\text { Nilai } \\
\text { Terend } \\
\text { ah }\end{array}$ & $\begin{array}{l}\text { Nilai } \\
\text { Tertin } \\
\text { ggi }\end{array}$ & $\begin{array}{l}\text { Nilai } \\
\text { Rata- } \\
\text { Rata }\end{array}$ \\
\hline 1 & Tes awal & 50.00 & 72.00 & 57,74 \\
\hline 2 & Tes akhir & 70.00 & 95.00 & 87,15 \\
\hline 3 & N-Gain & & & 0.68 \\
\hline
\end{tabular}

Berdasarkan tabel 4 tersebut dapat dibuat dalam diagram batang $\mathrm{KBKr}$ siswa tanpa menggunakan model PBL pada gambar 4 berikut ini.

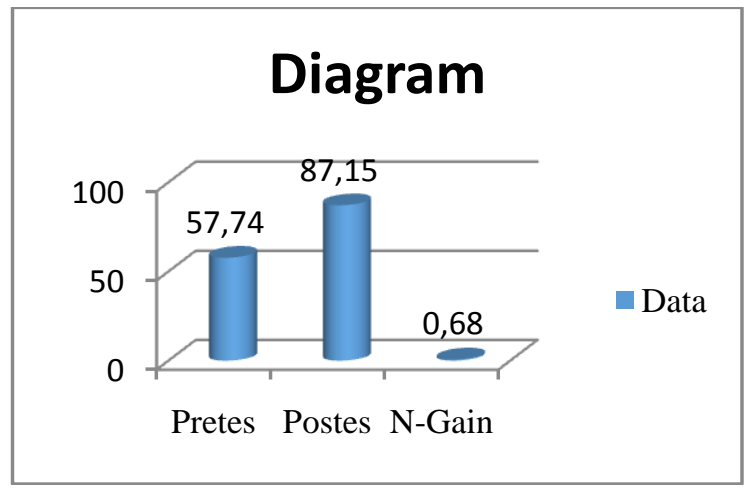

Gambar 4 Diagram Keterampilan Berfikir Kritis Siswa Tanpa Model PBL

Berdasarkan tabel 4 dapat dilihat nilai pretes kelas kontrol dengan tanpa menggunakan model PBL memiliki nilai tertinggi 72.00 dan nilai terendah 50.00 dengan rata-rata 57,74 (kriteria kurang). Adapun nilai hasil dari postest 95.00 nilai tertinggi dan nilai terendah 70.00 dengan rata-rata 87,15 (kriteria cukup) sedangkan nilai gain dari kelas kontrol memiliki ratarata 0.68 dengan kriteria sedang.

c. Analisis Data Indeks N-Gain Tes Awal dan Tes Akhir (Peningkatan KBKr Siswa dengan Menggunakan dan tanpa Menggunakan Model PBL pada Materi Pokok Alat Indra)

Tabel 5 Rata-Rata $N$-Gain Indikator $\mathrm{KBKr}$

\begin{tabular}{|c|c|c|c|c|c|}
\hline \multirow[b]{2}{*}{ No } & \multirow{2}{*}{$\begin{array}{c}\text { Indikator } \\
\mathbf{K B K r}\end{array}$} & \multicolumn{2}{|c|}{ Eksperimen } & \multicolumn{2}{|c|}{ Kontrol } \\
\hline & & $\begin{array}{c}\text { Rat } \\
\text { a- } \\
\text { rata }\end{array}$ & $\begin{array}{c}\text { Kateg } \\
\text { ori }\end{array}$ & $\begin{array}{c}\text { Rat } \\
\text { a- } \\
\text { rata }\end{array}$ & $\begin{array}{c}\text { Kate } \\
\text { gori }\end{array}$ \\
\hline 1 & $\begin{array}{l}\text { Memberik } \\
\text { an } \\
\text { Penjelasan } \\
\text { Sederhana }\end{array}$ & 0.51 & $\begin{array}{l}\text { Sedan } \\
\mathrm{g}\end{array}$ & 0,24 & $\begin{array}{l}\text { Rend } \\
\text { ah }\end{array}$ \\
\hline 2 & $\begin{array}{l}\text { Membang } \\
\text { un } \\
\text { Keterampi } \\
\text { lan Dasar }\end{array}$ & 0,45 & $\begin{array}{l}\text { Sedan } \\
\mathrm{g}\end{array}$ & 0,31 & $\begin{array}{l}\text { Rend } \\
\text { ah }\end{array}$ \\
\hline 3 & $\begin{array}{l}\text { Menyimpu } \\
\text { lkan }\end{array}$ & 0.49 & $\begin{array}{l}\text { Sedan } \\
\mathrm{g}\end{array}$ & 0,40 & $\begin{array}{l}\text { Rend } \\
\text { ah }\end{array}$ \\
\hline 4 & $\begin{array}{l}\text { Memberik } \\
\text { an } \\
\text { Penjelasan }\end{array}$ & 0,35 & $\begin{array}{l}\text { Sedan } \\
\mathrm{g}\end{array}$ & 0,15 & $\begin{array}{l}\text { Rend } \\
\text { ah }\end{array}$ \\
\hline
\end{tabular}




\begin{tabular}{|l|l|l|l|l|}
\hline Lanjut & & & & \\
\hline Rata-rata & $\mathbf{0 , 4 5}$ & $\begin{array}{l}\text { Sedan } \\
\text { g }\end{array}$ & $\mathbf{0 , 2 7}$ & $\begin{array}{l}\text { Ren } \\
\text { dah }\end{array}$ \\
\hline
\end{tabular}

Berdasarkan data dari tabel 5 Pengaruh penggunaan model PBL dalam materi alat indra pada kelas eksperimen dan tanpa model PBL pada kelas kontrol dapat dilihat dari perolehan nilai rata-rata $N$-Gain pada kedua kelas yang digunakan. Peningkatan kelas eksperimen sebesar 0,45, sedangkan peningkatan kelas kontrol sebesar 0,27. Dapat disimpulkan bahwa pengaruh penggunaan model PBL kelas eksperimen lebih baik dari pada kelas kontrol. Untuk mengetahui rata-rata $N$-Gain indikator pembelajaran dapat dilihat pada tabel 6 berikut.

\section{Pembahasan Hasil Penelitian}

a. Keterlaksanaan Proses Pembelajaran yang Menggunakan Model PBL dan Tanpa Menggunakan Model PBL pada Materi Alat indra.

Untuk melihat keterlaksanaan proses pembelajaran dilakukan pengamatan mengenai aktivitas guru dan siswa pada setiap tahapan pembelajaran yang dilakukan pada kelas eksperimen yang menggunakan model PBL dan kelas kontrol. Dalam pembelajaran dengan model PBL dilakukan penilaian keterlaksanaan proses pembelajaran oleh observer baik untuk penilaian guru maupun siswa. Dari hasil proses tersebut didapat bahwa proses keterlaksanaan model PBL dapat terlaksana pada pertemuan 1, 2 dan 3. Pada keterlaksanaan guru, pertemuan pertama mendapat hasil 79,49\% dengan kategori baik, dan pada pertemuan kedua mendapat skor $94,44 \%$ dengan kategori Sangat Baik dan pertemuan ke tiga mendapat skor 91,67\% dengan kategori sangat baik. Sedangkan pada keterlaksanaan siswa pada pertemuan pertama mendapat skor $88,88 \%$ dengan kategori sangat baik, dan pada pertemuan kedua mendapat skor $95,55 \%$ dengan kategori sangat baik dan pertemuan ketiga mendapat 97,78\% dengan kategori sangat baik.
Begitupun pada kelas kontrol proses keterlaksanaan dapat berjalan dengan baik pada pertemuan 1 dan 2 dan 3 . Pada keterlaksanaan guru, pertemuan pertama mendapat skor $76,92 \%$ dengan kategori Baik, dan pada pertemuan kedua mendapat skor $88,88 \%$ dengan kategori sangat baik dan pertemuan ketiga mendapat skor 91,67\% dengan kategori sangat baik. Sedangkan pada keterlaksanaan siswa pada pertemuan pertama mendapat skor $86,67 \%$ dengan kategori Sangat Baik, dan pada pertemuan kedua mendapat skor $82,00 \%$ dengan kategori Sangat Baik dan pertemuan ketiga dengan skor $92,67 \%$ dengan sangat baik.

Keterlaksanaan proses pembelajaranyang dilihat dari aktivitas guru dan siswa baik untuk kelas kontrol maupun kelas eksperimen dengan menggunakan lembar observasi. Hasil rata-rata presentase aktivitas guru yang menggunakan model PBL sebesar 88,53\% dengan kategori sangat baik dan untuk rata-rata presentase aktivitas guru tanpa menggunakan model PBL sebesar 85,82\% dengan kategori baik. Sedangkan untuk hasil rata-rata presentase aktivitas siswa yang menggunakan model PBL sebesar 87,40\% dengan kategori sangat baik dan untuk hasil rata-rata presentase aktivitas siswa yang tidak menggunakan model PBL sebesar 87,11\% dengan kategori sangat baik.

Hasil presentase rata-rata aktivitas guru dan siswa yang menggunakan model PBL lebih tinggi dari pada aktivitas guru dan siswa yang tidak menggunakan model PBL yaitu dengan hasil rata-rata yang menggunakan model PBL 87,97\% dan untuk yang tidak menggunakan model PBL sebesar 86,46\%. Hal ini terjadi karena pembelajaran yang menggunakan model PBL lebih menarik minat siswa untuk selalu ikut berpartisipasi aktif dalam pembelajaran, tidak seperti yang pembelajarannya tidak menggunakan model PBL yang cenderung siswa akan mudah bosan untuk mengikuti pelajaran. Walau demikian aktivitas guru dan siswa yang menggunakan dan tidak menggunakan 
model PBL menunjukan hasil presentase yang sama yaitu sangat baik.

\section{Peningkatan KBKr Siswa dengan Menggunakan Model PBL}

Dari data hasil penelitian menunjukan bahwa $\mathrm{KBKr}$ siswa pada materi alat indra dengan menggunakan model PBL mengalami perbedaan hasil belajar. Hal ini terbukti dengan adanya perbedaan nilai rata-rata pretest, posstest dan $N$-Gain yang diperoleh. Nilai rata-rata pretest sebesar 62,93, posstest sebesar 88,51 . Rata-rata nilai perindikator $N$-Gain sebesar 0,45 dengan katagori Sedang. Ratarata niali $N$-Gain paling tinggi sebesar 0,51 pada aspek memberikan penjelasan sederhana dan paling rendah sebesar 0,35 pada aspek memberikan penjelasan lanjut.

Menurut flavell (1963) dalam Dahar (1996 : 155), usia siswa sekolah menengah atas termasuk kedalam tingkat operasional formal dimana pada usia ini siswa dapat merumuskan banyak alternative hipotesis dalam menanggapi masalah, dan mencek data terhadap setiap hipotesis untuk membuat keputusan yang layak.

Berdasarkan nilai tersebut dapat diketahui bahwa data-data yang diperoleh mengenai penggunaan model PBL pada materi alat indra dapat meningkat, artinya bahwa penggunaan model PBL yang dikembangkan mempengaruhi (KBKr) siswa.

Hasil penelitian ini pun sejalan dengan yang dilakukan oleh Lindawati (2009) tentang imlpementasi PBL untuk meningkatkan $(\mathrm{KBKr})$ siswa pada konsep reaksi kimia. Menunjukkan adanya peningkatan keterampilan berfikir kritis siswa dengan hasil analisis $t_{\text {hitung }}(2.20)>$ $\mathrm{t}_{\text {tabel }}$ (2.03) dengan nilai rata-rata 81,25 dari pertemuan pertama dengan nilai 68.75 dan kedua dengan nilai 93.75 .

Adapun hasil penelitian yang telah dibuktikan juga oleh Nuryanti lestari dalam pembelajaran dengan menggunakan metode PBL pada materi laju reaksi. Dari hasil penelitian nya pada tahun (2010) menunjukkan bahwa metode PBL $94.00 \%$ teraplikasi dengan baik dan meningkatkan kreaktifan serta motivasi belajar siswa terhadap materi laju reaksi berpengaruh positif dan signifikan.

\section{Peningkatan KBKr Siswa tanpa Menggunakan Model PBL}

Menurut data rekapitulasi hasil belajar siswa yang tanpa menggunakan model PBL pada kelas kontrol memperoleh nilai ratarata pretest kelas kontrol sebesar 53,17 dengan kategori cukup pada aspek membangun keterampilan dasar dan yang terendah sebesar 30,95 pada aspek memberikan penjelasan lanjut. Rata-rata nilai per-indikator $N$-Gain diperoleh sebesar 0,15 dengan kualifikasi rendah pada aspek memberikan penjelasan lanjut. Ratarata nilai $N$-Gain paling tinggi sebesar 0,40 pada aspek menyimpulkan data posttest sebesar 87,15 dan $\mathrm{N}$-Gain sebesar 0,24 dengan kategori rendah.

Aspek menyimpulkan data mendapatkan rata-rata nilai tertinggi baik dalam tes awal maupun tes akhir dalam rata-rata nilai $N$ Gain. Dalam pembelajaran tanpa menggunakan model PBL pada kelas kontrol, proses pembelajaran berlangsung sesuai dengan kegiatan yang biasanya dilakukan di SMAN 9 Garut tanpa diberikan pengaruh (treatment) apapun. Maka perbedaan hasil belajar siswa antara yang menggunakan model PBL pada kelas eksperimen dengan tanpa menggunakan model PBL pada kelas kontrol dilihat dari skor hasil pretest, posttest, dan $N$-Gain dimana terdapat perbedaan yang cukup signifikan di antara kedua kelas tersebut.

\section{Pengaruh Penggunaan Model PBL terhadap KBKr Siswa}

Perolehan nilai rata-rata tes akhir pada kelas eksperimen berada di diatas batas ketuntasan belajar minimal yaitu 97,00 dimana ketuntasan belajar minimal di sekolah tempat dilakukannya penelitian sebesar 73,00. Hal ini berarti penggunaan strategi pembelajaran yang disampaikan sudah efektif dalam penelitian ini. Sedangkan untuk nilai rata-rata tes akhir kelas kontrol juga diatas dari ketuntasan belajar minimal yaitu sebesar 73,00. 
Adapun faktor yang mempengaruhi hasil penelitian beberapa diantaranya seperti sikap siswa terhadap pembelajaran, prosedur pembelajaran yang disampaikan oleh guru, lingkungan yang nyaman dan kondusif juga mempengaruhi hasil belajar siswa. Menurut Syah (2008: 132), faktorfaktor yang mempengaruhi belajar siswa secara global terbagi ke dalam tiga macam yaitu : 1) Faktor internal (faktor dari dalam diri siswa), yakni keadaan atau kondisi jasmani dan rohani siswa; 2) Faktor eksternal (faktor dari luar), yakni kondisi lingkungan disekitar siswa; 3) Faktor pendekatan belajar (approach to learning), yakni jenis upaya belajar siswa yang meliputi strategi dan metode yang digunakan siswa untuk melakukan kegiatan pembelajaran materi pelajaran.

Pengaruh peningkatan $\mathrm{KBKr}$ siswa dalam materi pokok alat indra dengan menggunakan model PBL dapat dilihat dari pengujian hipotesis yang dilakukan. Hasil uji normalitas tes awal dengan menggunakan model PBL dan tanpa menggunakan model PBL berdistribusi Normal, sedangkan tes akhir dan $\mathrm{N}$-Gain dengan menggunakan model PBL dan tanpa menggunakan model PBL berdistribusi Tidak Normal, karena $\mathrm{X}_{\text {hitung }}^{2}>\mathrm{X}_{\text {tabel. }}^{2}$ Dikarenakan data berdistribusi tidak normal, maka dilakukan uji men-whitney. Berdasarkan data hasil penelitian dapat disimpulkan bahwa penggunaan model PBL berpengaruh positif terhadap keterampilan berpikir kritis siswa dan layak untuk digunakan dalam proses belajar mengajar. Hal ini ditunjukkan dengan nilai $Z_{\text {hitung }}>Z_{\text {tabel }}$, yaitu $1,0>1,66$. Maka $\mathrm{H}_{\mathrm{a}}$ diterima dan $\mathrm{H}_{0}$ ditolak. Dengan demikian, penggunaan model PBL dalam materi alat indra dapat meningkatkan $\mathrm{KBKr}$ siswa.

\section{Kesimpulan}

Berdasarkan hasil penelitian diperoleh kesimpulan sebagai berikut :

1. Peningkatan $\mathrm{KBKr}$ siswa pada materi alat indra dengan menggunakan model PBL memiliki nilai rata-rata pretest sebesar 62,93, posstest sebesar 88,51.
Rata-rata nilai perindikator $N$-Gain sebesar 0,45 dengan katagori Sedang. Rata-rata niali $N$-Gain paling tinggi sebesar 0,51 pada aspek memberikan penjelasan sederhana dan paling rendah sebesar 0,35 pada aspek memberikan penjelasan lanjut. Sedangkan tanpa menggunakan model PBL nilai rata-rata pretest kelas kontrol sebesar 57,74 posttest sebesar 87,15 dan N-Gain sebesar 0,24 dengan kategori rendah.

2. Hasil belajar terhadap $\mathrm{KBKr}$ siswa lebih besar dari pada siswa yang tanpa menggunakan model PBL. Dilihat dari perolehan nilai rata-rata gain kelas eksperimen sebesar 29.41 sedangkan perolehan nilai rata-rata gain kelas kontrol sebesar 26.58.

3. Sikap siswa terhadap pembelajaran dengan model PBL mendapatkan respon positif.

\section{Daftar Pustaka}

Amir, Taufiq M. 2010. Inovasi Pendidikan Melalui Problem Based Learning. Jakarta; Kencana Prenada Media Group.

Arifin, Zaenal. 2009. Evaluasi Pembelajaran. Bandung; Rosda Karya.

Arikunto,Suharsimi. 2009. Dasar-dasar Evaluasi Pendidikan. Jakarta; PT Bumi Aksara. 2006. Prosedur Penelitian Suatu Pendekatan Praktik. Jakarta; PT Rineka Cipta.

BSNP. (2006). Kurikulum Tingkat Satuan Pendidika.Jakarta : Direktorat Pembinaan SMA

Campbell, Reece et al. 2002. Biologi Jilid I. Jakarta; Erlangga. 2003. Biologi Jilid II. Jakarta; Erlangga. 2004. Biologi Edisi KelimaJilid 3. Jakarta : PT Gelora Aksara Pratama.

Depag RI, 2004. Al-Quran Dan Terjemahannya. Bandung; Diponegoro. 
Diastuti, Reni.2009.Biologi SMA Kelas XI jilid 2.Jakarta: Pusat Perbukuan

Ennis R.H. 1985. Goals For A Critical Thinking Curriculum. In Costa, A.L. (ed). Developing Mind : A Resource Book For Teaching Thinking. Virginia: ASDC Alexandria.

Fathurrohman, Pupuh, dkk. 2007. Strategi Belajar Mengajar. Bandung: Refika Aditama.

Hamalik, Oemar. 2007. Psikologi Proses Belajar dan Mengajar. Bandung; Sinar Baru Algensindo.

Hassaubah, Zaleha. 2007. Mengasah Pikiran Kreatif dan Kritis. Bandung; Nuansa.

Hidayat, M. Taufik. 2008. Model Pembelajaran Inkuiri Pada Sub Topic Pembiasan Cahaya Oleh Lensa Untuk Meningktakan Pemahaman Konsep Dan Keterampilan Berfikir Kritis Siswa SMA. Skripsi Pasca Sarjana UPI; Tidak Diterbitkan.

http://www.google.co.id/search Pustekkom depdiknas@2008

http:///www.crayonpedia.org/mw/sistem_k oordinasi_dan_alat_indera_pada manusia_9.1_dewi_ganawati

Isjono. 2011. Cooperatif Learning. Yogyakarta: Alfabeta.

Johson, B Elaine. 2011. Contextual Teaching Dan Learning. Bandung; kaifa.

Kariadinata, Rahayu. 2008. Dasar- Dasar Statistik Pendidikan. Bandung. UIN Bandung.

Kindersley, Dorling. 2007. Kehidupan. Jakarta; Balai Pustaka.

Kuzhumannii, varughese. 2009. Effect Of Student Approaches To Learning On Performance In Two Pedagogic Environments.

http://www/ccsenet.org/journal.html

Lestari , Nurhayati. 2010. Penerapan Model Problem Based Learning (PBL) Pada Pembelajaran Subkonsep Factor-Faktor
Mempengaruhi Laju Reaksi. Skripsi KIMIA UIN; Tidak diterbitkan.

Majid, Abdul. 2009. Perencanaan Pengajaran. Bandung; PT Remaja Rosdakarya.

Moleong, J Lexy. 1988. Metode Penelitian Kualitatif. Bandung ; Ghalia Indonesia.

Nurmaniah, Nia. 2006. Keterampilan Berfikir Kritis Siswa Hubunganya Dengan Hasil Belajar Dalam Subkonsep Pewarisan Sifat. Skripsi BIOLOGI UIN. Tidak diterbitkan.

Pearce, Evelyn. 1991. Anatomi dan Fisiologi Untuk Paramedis. Jakarta; Gramedia Pustaka.

Rusmono. 2012. Strategi Pembelajaran Dengan Problem Based Learning. Bogor; Ghalia Indonesia.

Ruswandi, Uus,dkk. 2008. Landasan Pendidikan. Bandung; Insan Mandiri.

Setiati, Sri. 2011. Penerapan PBL Untuk Meningkatkan Hasil Belajar Siswa Pada Konsep Alat Indra. Skripsi BIOLOGI UIN. Tidak diterbitkan.

Subana, dkk. 2009. Statistik Pendidikan. Bandung; Pustaka Setia.

Sudarman.2007.Problem Based Learning Jurnal Pendidikan Inovatif, vol $2.6873130 \quad$ (available online: http//www.google.com diakses 10 januari 2014)

Sugiyono. 2009. Statistika Untuk Penelitian. Bandung; Alfabeta.

Syah, Muhibin. 2005. Psikologi Pendidikan Dengan Pendekatan Baru. Bandung; Rosda Karya

Sutrisno, joko. 2008. Menggunakan Keterampilan Berfikir Kritis Untuk Meningkatkan Mutu Pembelajaran. [online]. Tersedia; http://joko.tblog.com/post/19699866 16. [diakses 3 februari 2014].

Widiastuti, retno.2009.Penerapan Model Problem Based Learning disertai media gambar untuk meningkatkan kemandirian belajar siswa dalam biologi.jurnal pendidikan. 